\title{
Echinococcus granulosus infection in foxes in Coquimbo District, Chile
}

\author{
Infección por Echinococcus granulosus en zorros en la Región de Coquimbo, Chile
}

\author{
G Acosta-Jamett ${ }^{\mathrm{a}, \mathrm{b}, \mathbf{c}^{*}}$, S Cleaveland ${ }^{\mathrm{d}}$, BM de C Bronsvoort ${ }^{\mathrm{a}}$, AA Cunningham ${ }^{\mathrm{b}}$, H Bradshaw $^{\mathrm{e}}$, PS Craig ${ }^{\mathrm{e}}$

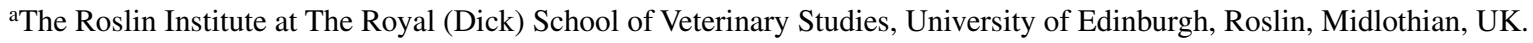 \\ bInstitute of Zoology, Zoological Society of London, Regent's Park, London, UK. \\ 'Instituto de Medicina Preventiva Veterinaria y Programa de Investigación Aplicada en Fauna Silvestre, Facultad de Ciencias \\ Veterinarias, Universidad Austral de Chile, Valdivia, Chile. \\ ${ }^{\mathrm{d} B o y d}$ Orr Centre for Population and Ecosystem Health, Institute of Biodiversity, Animal Health and Comparative Medicine, \\ University of Glasgow, Glasgow, UK. \\ ${ }^{\text {e}}$ Cestode Zoonoses Research Group, Bioscience Research Institute and School of Environment and Life Sciences, University of \\ Salford, Greater Manchester, UK.
}

\begin{abstract}
RESUMEN
Echinococcus granulosus es un cestodo de importancia zoonótica que afecta a una amplia gama de especies. El principal hospedero definitivo de este parásito es el perro doméstico, sin embargo, en algunas áreas del mundo se ha reportado la infección de carnívoros silvestres con este, estos potencialmente podrían tener un rol en la mantención de la infección en dichas áreas. Este estudio examina la presencia de E. granulosus en carnívoros silvestres en la Región de Coquimbo en Chile; para esto se obtuvieron muestras fecales de zorros chilla y culpeo capturados en seis sitios rurales de esta región entre 2005 y 2006. Mediante una prueba de ELISA coproantígeno se determinó una coproprevalencia a E. granulosus en chillas de 7\% (2/28), la que varió entre $0 \%$ a $20 \%$ en los diferentes sitios estudiados. Solo cinco culpeos fueron capturados y ninguno fue positivo. Se discuten las implicancias que la presencia de E. granulosus en carnívoros silvestres podría tener para la mantención del parásito en el área estudiada.
\end{abstract}

Palabras clave: Echinococcus granulosus, ELISA coproantígeno, carnívoros silvestres.

\section{SUMMARY}

Echinococcus granulosus is a cestode of zoonotic importance that infects a wide range of animals. The main definitive host of this parasite is the domestic dog, which most commonly becomes infected by ingestion of infected tissues from ruminant livestock. In some areas, however, wild carnivores have been reported to be infected with E. granulosus and to potentially have a role in the maintenance of infection. This study explores $E$. granulosus infection in free-ranging foxes in rural areas of the Coquimbo District. Faecal samples of live-trapped culpeo (Lycalopex culpaeus) and chilla ( $L$. griseus) foxes were obtained in six of previously designed rural sites of the Coquimbo District in Chile between 2005 and 2006. Overall, E. granulosus coproantigen prevalence in chillas by a coproELISA test was $7 \%(2 / 28)$ and ranged from $0 \%$ to $20 \%$ in the different study sites. Only five culpeos were trapped and none was positive. The presence of E. granulosus in wild carnivores for the maintenance of this parasite in this District is discussed.

Key words: Echinococcus granulosus, ELISA coproantigen, wild carnivores.

\section{INTRODUCTION}

Echinococcus granulosus is a cestode of zoonotic and veterinary importance that affects a wide range of animals (Cardona and Carmena 2013). This parasite occurs on all continents, being known from $\sim 100$ countries. The southern part of South America, comprising Argentina, Brazil, Chile, Perú and Uruguay, is an endemic area with high infection prevalence (Eckert and Deplazes 2004, Moro and Schantz 2006).

The adult cestode stage of this parasite inhabits the small intestine of carnivores, the definitive host, and produces eggs containing infective oncospheres. Either

Accepted: 18.12.2014.

* gerardo.acosta@uach.cl cestode segments (proglotids) containing eggs or free eggs are released from the intestinal tract of the carnivore via faeces into the environment. Intermediate host species, mainly ungulates, feeding on contaminated pastures ingest the contaminated eggs and the larval stage, the metacestode, develops in their internal organs. In these hosts, the parasite causes a range of clinical signs, depending on its location. The incidental ingestion of E. granulosus eggs can occur by "aberrant" hosts that do not play a role in the natural cycle, such as human beings (Eckert and Deplazes 2004). As in intermediate hosts, the parasite forms cysts in the organs of infected people, a condition known as cystic echinococcosis (CE). It can, however, take several months to years post-ingestion before signs of hydatid disease become apparent (Pawlowski et al 2001, Torgerson and Budke 2003). 
The diagnosis of intestinal E. granulosus infection in living canids is difficult by routine coproscopic techniques, which cannot be differentiated by light microscopy from the eggs of other Echinococcus species or Taenia species. ELISAs for detecting parasite antigens in faecal samples (coproantigens) have been used in recent years and allow the rapid screening of live animals (Deplazes et al 1994, Craig et al 1995, Jenkins et al 2000, Craig et al 2003, Moro et al 2005). Current coproantigen ELISAs for $E$. granulosus are reported to have a high sensitivity (close to $90 \%$ ) and specificity (over 98\%) (Deplazes et al 1992, Allan and Craig 2006).

In spite of successful long-term control programs in some restricted regions in Argentina, Brasil, Chile and Uruguay, hydatidosis is still endemic in many regions of the continent (Cardona and Carmena 2013). Sheep are the main intermediate host for the G1 genotype of E. granulosus, which has a worldwide distribution including South America (McManus and Thompson 2003). Although some studies have been carried out in South America on the epidemiology of hydatidosis (Moro et al 1997, Larrieu et al 2000, Moro et al 2004, Moro et al 2005, Moro and Schantz 2006), there are still many aspects of its epidemiology that need to be explored to develop appropriate control strategies. One of those aspects is the role of wild carnivores in the epidemiology of $E$. granulosus.

The main definitive reservoir of E. granulosus is the domestic dog; however in certain regions wild carnivores have been reported to be infected with $E$. granulosus by preying on infected intermediate hosts, having a potential role in the maintenance of infection (Jenkins and Macpherson 2003, Banks et al 2006, Lahmar et al 2009). In areas where wild carnivores predate or scavenge livestock infected with $E$. granulosus, they are likely to consume the oncosphere stage in the carcass and may provide an additional or alternative final host for the maintenance of the parasite, as has been being found for other parasites (Stuart et al 2013).

Two wild canids inhabit the Coquimbo region of north-central Chile: culpeo (Lycalopex culpaeus) and chilla (Lycalopex griseus) foxes (Muñoz-Pedreros and Yañez 2000). These are medium-sized wild canids, the culpeo fox weighing between $4-14 \mathrm{~kg}$ and the chilla fox weighing between $2-5 \mathrm{~kg}$ (Jiménez and Novaro 2004), both of them live in the western part of South America. Despite their relatively small size, culpeo and chilla foxes are known predators and/or scavengers of livestock (Silva-Rodríguez et al 2009) and are a cause of human-wildlife conflict, particularly in the semiarid northern-central areas of Chile.

In the Coquimbo District, the human incidence of CE ranges from 2.3 to 8.5 cases per 100,000 inhabitants (Acosta-Jamett et al 2010 $)$. This compares to a prevalence of CE in livestock of 7\% to 25\% (Acosta-Jamett et al 2010 and a prevalence of infection with E. granulosus of $7 \%$ to
$22 \%$ in domestic dogs (Sabelle 2001, Acosta-Jamett et al $2010^{\mathrm{b}}$, Acosta-Jamett et al 2014).

The aim of the current study was to assess whether wild foxes in the Coquimbo District were infected with E. granulosus.

\section{MATERIAL AND METHODS}

\section{STUDY AREA}

The study area comprised approximately $1,600 \mathrm{~km}^{2}$ in the Coquimbo District, northern Central Chile ( $71^{\circ} 12^{\prime}$ to $71^{\circ} 40^{\prime} \mathrm{W}, 29^{\circ} 58^{\prime}$ to $30^{\circ} 39^{\prime} \mathrm{S}$ ). This area included the Fray Jorge National Park (FJNP), a protected area of 9,959 ha. We established seven study sites along two transects, with each transect running from FJNP through areas of increasing urbanisation to the cities of Ovalle or Coquimbo (figure 1). The "El Tangue" ranch, a private farm of nearly 45,000 ha situated $25 \mathrm{~km}$ north of FJNP (figure 1) is located in one of these transects.

\section{E. granulosus INFECTION IN FOXES}

Fifteen traps were evenly placed at $500 \mathrm{~m}$ intervals across each study site. At each site, wild foxes were captured using padded leg-hold traps (Victor Soft Catch No. 1.5, Chagnons Trapping Supply, Manistique, Michigan,

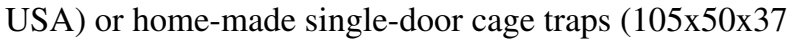
$\mathrm{cm}$ ) incorporating an internal squeeze panel. Leg-hold traps were anchored in the soil using an iron chain attached to two crossed metal stakes. Both types of trap were baited daily with tuna or chicken meat. Leg-hold traps were closed during periods of inclement weather (extreme cold) and during daytime to avoid unnecessary capture of non-target species. Traps were checked every six hours; a period of time that allowed trapping success without trapped foxes coming to harm. Foxes trapped in leg-hold traps were manually restrained with a hand-held small mesh butterfly-like net specially designed for the purpose and were then anesthetised via intramuscular injection.

Animals were anesthetised with one of three anaesthetic combinations [i.e. ketamine-medetomidine (with atipamezole reversal), ketamine-xylazine, or tiletamine-zolazepam (Acosta-Jamett et al 2010 a)]. While anaesthetised, a faecal sample (for E. granulosus analysis) was obtained by digital stimulation of the anus (Buishi et al 2005), or by collection of freshly-voided faeces at the capture site (Wang et al 2001). Prior to release, each animal sampled was individually marked using an eartag with a unique number to avoid re-sampling. Collected faeces were deposited in a 5\% phosphate-buffered saline formalin solution and kept at $+4{ }^{\circ} \mathrm{C}$ until analysis. To determine if an animal was positive for E. granulosus, an ELISA coproantigen test was carried out, as described by Craig et al. (1995). Capture and handling procedures were approved by the Ethics Committee at the Institute of Zoology, Zoological 

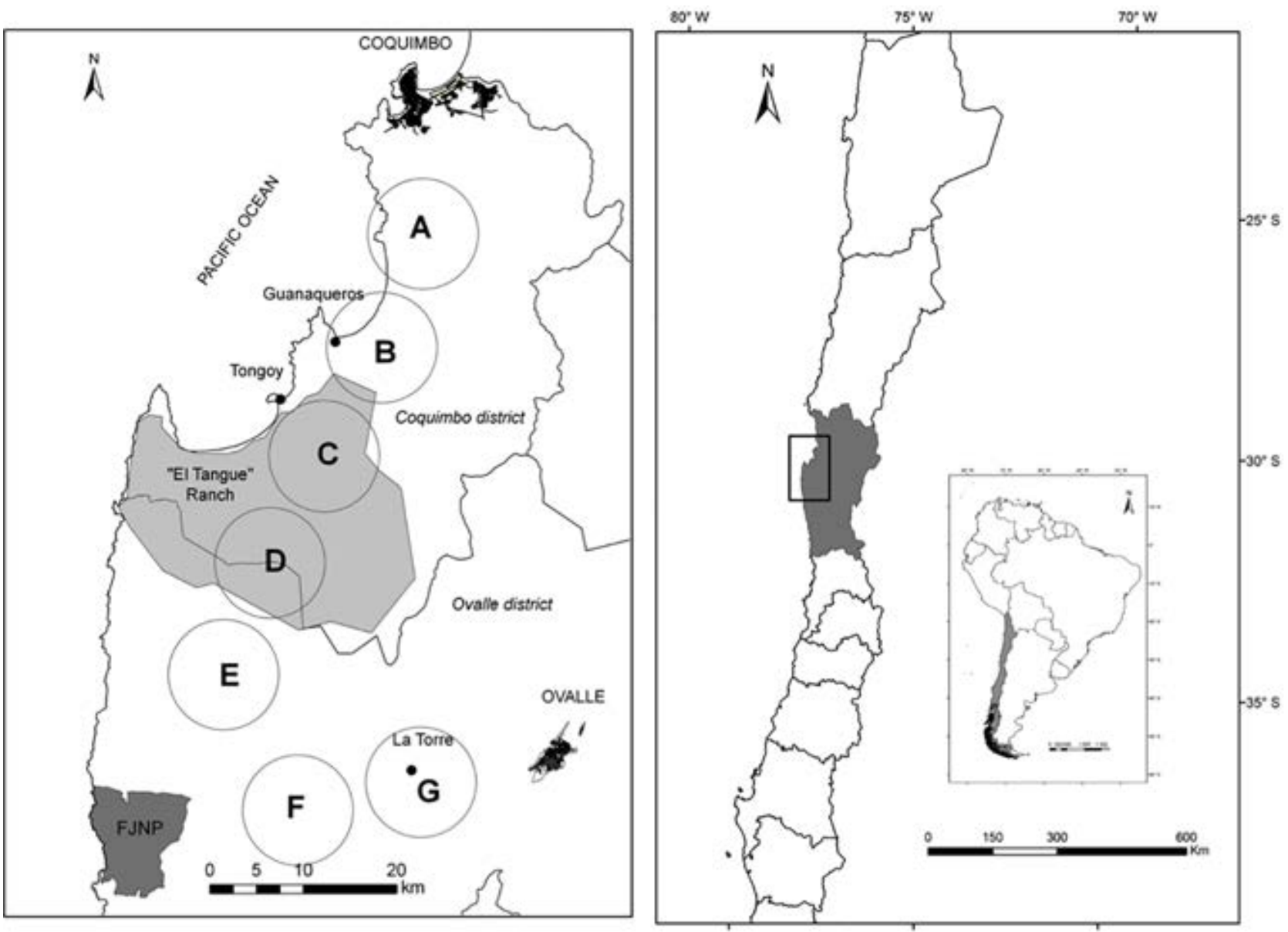

Figure 1. Study area. Two transects from Coquimbo and Ovalle cities to the Fray Jorge National Park (in dark gray) through rural sites are shown. Seven rural sites were delimited within which foxes were sampled. In pale grey the "El Tangue" ranch. White circles show small towns in the area.

Área de estudio. Se muestran dos transectos desde las ciudades de Coquimbo y Ovalle hacia el Parque Nacional Fray Jorge en sitios rurales. Siete sitios fueron delimitados en la zona de estudio, dentro de ellos fueron capturados los zorros silvestres. En gris claro se indica el fundo "El Tangue". En círculos blancos se muestran los pueblos existentes en el área.

Society of London and authorised by the Chilean Animal Health Service.

\section{RESULTS AND DISCUSSION}

Overall, 33 foxes were trapped, five of them were culpeos and 28 were chillas. Culpeos were trapped only in sites A (1), E (2) and F (2), while chillas were trapped in all sites except in site $\mathrm{G}$, where no animals were trapped (table 1). Due to the small number of culpeos tested, Echinococcus coproELISA prevalence is given for chillas only. E. granulosus coproantigen was detected only in two of the foxes sampled: two chillas, one from site $\mathrm{C}$ and one from site D. Each of these sites included part of the "El Tangue" ranch (table 1).

Although the prevalence was generally low $(2 / 28$, $7.1 \%$ positive), it was similar to that previously reported in domestic dogs in the same study areas $(10 / 214,5 \%$ individuals positive) (Acosta-Jamett et al 2010 $)$. Sites C
Table 1. Number of samples and E. granulosus coproantigen prevalence in chillas in each rural site in the Coquimbo District, in parenthesis the $90 \% \mathrm{CI}$.

Número de muestras y prevalencia de coproantígeno de $E$. granulosus en carnívoros silvestres en cada sitio rural de la Región de Coquimbo, en paréntesis se indican el 90\% IC.

\begin{tabular}{lccc}
\hline Sites & No. chillas & $\begin{array}{c}\text { No. positive } \\
\text { chillas }\end{array}$ & $\begin{array}{c}\text { E. granulosus } \\
\%(90 \% \text { CI })\end{array}$ \\
\hline A & 4 & 0 & $0(0-37)$ \\
B & 6 & 0 & $0(0-39)$ \\
C & 7 & 1 & $14(1-52)$ \\
D & 5 & 1 & $20(1-66)$ \\
E & 2 & 0 & $0(0-54)$ \\
F & 4 & 0 & $0(0-37)$ \\
Total & 28 & 2 & $7(2-18)$ \\
\hline
\end{tabular}


\& D comprise the "El Tangue" ranch, where around 10,000 sheep are raised every year and where CE is commonly seen when these animals are slaughtered ${ }^{1}$ which could pose a factor for wild foxes infection with E. granulosus by predation or scavenging.

Predation of livestock by wild carnivores is a common phenomenon across Chile (Soto 2001). In Tierra del Fuego island in Magallanes District, Aguilera (2001) estimated a $2.2 \%$ (i.e. 1 of 45 animals) prevalence in hunted chillas, and Gómez-Figueroa (2005) determined that when chilla foxes were fed sheep tissues containing viable and fertile E. granulosus cysts, the parasite is able to develop to patency in the gut of the fox. Also in Tierra del Fuego, Zanini et al (2006) estimated a $1.2 \%$ prevalence of E. granulosus infection of 81 necropsied chilla foxes. If livestock in areas of endemic infection with E. granulosus is predated or scavenged by foxes, then it is likely that these carnivores can act as definitive hosts.

Although the coproELISA test has been used widely for testing E. granulosus infection our estimates of infection prevalences are uncertain given the small sample size and cross reactivity with other cestodes, such as Taenia sp. (Christophi et al 2002). Nevertheless, our findings suggest that under the field conditions found in our study site, optimal circumstances for the wild carnivores to participate in the cycle of this parasitic disease through the predation or scavenging of livestock and/or through a wild cycle similar to that reported in other countries could exist (Jenkins and Macpherson 2003). This has not previously been reported or considered in the Coquimbo District and further studies involving larger sample sizes both for chilla and culpeo fox are needed to test this hypothesis. Additionally, future studies should include other diagnostic tools such as PCR for reducing cross reactivity with other tests. If the wild fox population is able to sustain E. granulosus independently of dogs, this has implications for the control and elimination of E. granulosus from livestock. For example, control measures might need to include the prevention of fox predation on, or scavenging of, livestock, in addition to dog worming programmes.

\section{ACKNOWLEDGEMENTS}

This study was supported by a grant from the Ministry of Development and Planning of Chile (MIDEPLAN). The Field Veterinary Program, Wildlife Conservation Society, the Small Project Grant at the University of Edinburgh Development Trust, Idea Wild, the BirrellGray Traveling Scholarship at the School of Veterinary Studies, University of Edinburgh provided funding for the fieldwork and travel expenses. Dr. F. Astorga, Dr. F. Hernández and Dr. D. Donoso and Mr. G. Vega for field assistance. Dr. D. Shaw and E. Fevre provided advice on the early stage of this study. The Chilean Animal Health Service (SAG), the Corporación Nacional Forestal (CONAF), Dr. Julio Gutiérrez and Mr. Julio Bonilla provided logistical support for which we are most grateful.

Ranch personnel, personal communication.

\section{REFERENCES}

Acosta-Jamett G, F Astorga-Arancibia, AA Cunningham. 2010 . Comparison of chemical immobilization methods in wild foxes (Pseudalopex griseus and P. culpaeus) in Chile. J Wildl Dis 46, 1204-1213.

Acosta-Jamett G, S Cleaveland, BMd Bronsvoort, AA Cunningham, H Bradshaw, PS Craig. 2010 . Echinococcus granulosus infection in domestic dogs in urban and rural areas of the Coquimbo region, north-central Chile. Vet Parasitol 169, 117-122.

Acosta-Jamett G, S Cleaveland, BMd Bronsvoort, AA Cunningham, H Bradshaw, PS Craig. 2010 c. Echinococcus granulosus infection in human and livestock in the Coquimbo region, north-central Chile. Vet Parasitol 169, 102-110.

Acosta-Jamett G, T Weitzel, B Boufana, C Adones, A Bahamonde, K Abarca, PS Craig, I Reiter-Owona. 2014. Prevalence and risk factors for echinococcal infection in a rural area of northern Chile: a household-based cross-sectional study. PLoS Negl Trop Dis 8, e3090.

Aguilera JC. 2001. Estudio preliminar de equinococosis y helmintos gastrointestinales en zorro gris (Pseudalopex griseus) silvestre de Tierra del Fuego, Chile. Undergraduate thesis, Universidad de Concepción, Chillán, Chile.

Allan JC, PS Craig. 2006. Coproantigens in taeniasis and echinococcosis. Parasitol Int 55, S75-S80.

Banks DJD, DB Copeman, LF Skerratt. 2006. Echinococcus granulosus in northern Queensland. 2. Ecological determinants of infection in beef cattle. Aust Vet J 84, 308-311.

Buishi IE, EM Njoroge, O Bouamra, PS Craig. 2005. Canine echinococcosis in northwest Libya: assessment of coproantigen ELISA, and a survey of infection with analysis of risk-factors. Vet Parasitol 130, 223-232.

Cardona GA, D Carmena. 2013. A review of the global prevalence, molecular epidemiology and economics of cystic echinococcosis in production animals. Vet Parasitol 192, 10-32.

Christophi G, P Deplazes, N Christophi, I Tanner, P Economides, J Eckert. 2002. Screening of dogs for Echinococcus granulosus coproantigen in a low endemic situation in Cyprus. Vet Parasitol 104, 299-306.

Craig PS, RB Gasser, L Parada, P Cabrera, S Parietti, C Borgues, A Acuttis, J Agulla, K Snowden, E Paolillo. 1995. Diagnosis of canine echinococcosis-comparison of coproantigen and serum antibody tests with arecoline purgation in Uruguay. Vet Parasitol 56, 293-301.

Craig PS, MT Rogan, M Campos-Ponce. 2003. Echinococcosis: disease, detection and transmission. Parasitology 127, S5-S20.

Deplazes P, B Gottstein, J Eckert, DJ Jenkins, D Ewald, S JimenezPalacios. 1992. Detection of Echinococcus coproantigens by Enzyme Linked Immunosorbent Assay in dogs, dingoes and foxes. Parasitol Res 78, 303-308.

Deplazes P, S Jiménez-Palacios, B Gottstein, J Skaggs, J Eckert. 1994. Detection of Echinococcus granulosus coproantigens in stray dogs of northern Spain. Appl Parasitol 35, 297-301.

Eckert J, P Deplazes. 2004. Biological, epidemiological, and clinical aspects of echinococcosis, a zoonosis of increasing concern. Clin Microbiol Rev 17, 107-135.

Gómez-Figueroa CA. 2005. Contribución en la determinación del ciclo silvestre de Echinococcus granulosus en zorro gris (Pseudalopex griseus) silvestre en la XII región de Magallanes, Chile. Thesis, Universidad Austral de Chile, Valdivia, Chile.

Jenkins DJ, A Fraser, H Bradshaw, PS Craig. 2000. Detection of Echinococcus granulosus coproantigens in Australian canids with natural or experimental infection. J Parasitol 86, 140-145.

Jenkins DJ, CNL Macpherson. 2003. Transmission ecology of Echinococcus in wild-life in Australia and Africa. Parasitology 127, S63-S72.

Jiménez JE, AJ Novaro. 2004. Culpeo, Pseudalopex culpaeus. In: Sillero-Zubiri C, Hoffmann M, Macdonald DW (eds). Canids: Foxes, Wolves, Jackals and Dog: Status Survey and Conservation Action Plan. IUCN Publications Services Unit, Cambridge, UK, Pp 44-49.

Lahmar S, BS Boufana, S Lahmar, S Inoubli, M Guadraoui, M Dhibi, H Bradshaw, PS Craig. 2009. Echinococcus in the wild carnivores 
and stray dogs of northern Tunisia: the results of a pilot survey. Ann Trop Med Parasitol 103, 323-331.

Larrieu E, MT Costa, G Cantoni, JL Labanchi, R Bigatti, A Aquino, D Araya, E Herrero, L Iglesias, S Mancini, AS Thakur. 2000. Rate of infection and of reinfection by Echinococcus granulosus in rural dogs of the province of Rio Negro, Argentina. Vet Parasitol 87, 281-286.

McManus DP, RCA Thompson. 2003. Molecular epidemiology of cystic echinococcosis. Parasitology 127, S37-S51.

Moro PL, J McDonald, RH Gilman, B Silva, M Verastegui, V Malqui, G Lescano, N Falcon, G Montes, H Bazalar. 1997. Epidemiology of Echinococcus granulosus infection in the central Peruvian Andes. $B$ World Health Organ 75, 553-561.

Moro PL, L Lopera, M Cabrera, G Cabrera, B Silva, RH Gilman, MH Moro. 2004. Short report: Endemic focus of cystic echinococcosis in a coastal city of Peru. Am J Trop Med Hyg 71, 327-329.

Moro PL, L Lopera, N Bonifacio, A Gonzales, RH Gilman, MH Moro. 2005. Risk factors for canine echinococcosis in an endemic area of Peru. Vet Parasitol 130, 99-104.

Moro P, PM Schantz. 2006. Cystic echinococcosis in the Americas. Parasitol Int 55, S181-S186.

Muñoz-Pedreros A, J Yáñez 2000. Mamíferos de Chile (Valdivia, Editorial CEA), 460.

Novaro A. 1997. Pseudalopex culpaeus. Mamm Species 558, 1-8.

Pawlowski ZS, J Eckert, DA Vuitton, RW Ammann, P Kern, P Craig, FK Dar, FD Rosa, C Filice, B Gottstein, F Grimm, CNL Macpherson, N Sato, T Todorov, J Uchino, WV Sinner, H Wen. 2001. Echinococcosis in humans: clinical aspects, diagnosis and treatment. In: Eckert J,
Gemmell MA, Meslin F-X, Pawlowski ZS (eds). WHO/OIE manual on echinococcosis in humans and animals: a public health problem of global concern. World Organisation for Animal Health, Paris, France, Pp 20-66.

Sabelle C. 2001. Diagnóstico Equinococosis canina en la región de Coquimbo. Unpublished report, SAG IV Region. Ministerio de Agricultura. Chile.

Silva-Rodríguez EA, M Soto-Gamboa, GR Ortega-Solís, JE Jiménez. 2009. Foxes, people and hens: human dimensions of a conflict in a rural area of southern Chile. Rev Chil Hist Nat 82, 375-386.

Soto N. 2001. Impacto de la fauna silvestre en la producción agropecuaria de Magallanes. In Informe técnico: Servicio Agrícola y Ganadero (Punta Arenas).

Stuart P, A Zintl, T De Waal, G Mulcahy, C Hawkins, C Lawton. 2013. Investigating the role of wild carnivores in the epidemiology of bovine neosporosis. Parasitology 140, 296-302.

Torgerson PR, CM Budke. 2003. Echinococcosis - an international public health challenge. Res Vet Sci 74, 191-202.

Wang YH, MT Rogan, DA Vuitton, H Wen, B Bartholomot, CNL Macpherson, PF Zou, ZX Ding, HX Zhou, XF Zhang, J Luo, HB Xiong, Y Fu, A McVie, P Giraudoux, WG Yang, PS Craig. 2001. Cystic echinococcosis in semi-nomadic pastoral communities in north-west China. T Roy Soc Trop Med H 95, 153-158.

Zanini F, M Laferrara, M Bitsch, H Perez, MC Elissondo. 2006. Epidemiological studies on intestinal helminth parasites of the patagonian grey fox (Pseudalopex griseus) in Tierra del Fuego, Patagonia Argentina. Vet Parasitol 136, 329-334. 
